\title{
Multimeric forms of 4-1BBL as stimulators of $T$ cells for adoptive immunotherapy
}

\author{
Richard S Kornbluth" ${ }^{*}$, Victoria Snarsky ${ }^{1}$, Geoffrey W Stone ${ }^{2}$ \\ From Society for Immunotherapy of Cancer 29th Annual Meeting \\ National Harbor, MD, USA. 6-9 November 2014
}

Members of the TNF SuperFamily of ligands (TNFSFs) have significant potential as immuno-oncology therapeutic agents. The TNFSFs are trimeric membrane proteins that can be cleaved into soluble single trimers. While the soluble single trimers can be easily prepared and studied, they have little or no activity in vivo. This deficiency is caused by the need to cluster their cognate receptors in the plane of the membrane in order to induce a supramolecular signaling complex on the cytoplasmic side of the plasma membrane. For the TNFSF ligands, this requires that they be used as many-trimer multimers that mimic the natural expression of many trimers on the surface of stimulating cells. To meet this need, we prepared fusion proteins comprised of the extracellular domains of TNFSF ligands joined to a natural protein that provides a multimerization scaffold. When Acrp30 (a natural serum protein) is used as a scaffold, the result is a 2-trimer TNFSF ligand product (MegaLigand $^{\mathrm{TM}}$ ). When surfactant protein D (SPD) is used as a scaffold, the result is a 4-trimer TNFSF ligand product (UltraLigand ${ }^{\mathrm{TM}}$ ). Our published studies have described such multimeric forms of CD40L, OX40L, GITRL, CD27L/CD70, BAFF, RANKL, and TRAIL and shown that they are highly active in vitro and in vivo. As an extension of this work, 4-trimer forms of murine and human 4-1BBL (CD137L, TNFSF9) were constructed and expressed in $\mathrm{CHO}$ cells. As a co-stimulatory molecule, SPD-4-1BBL (Ultra4-1BBL ${ }^{\mathrm{TM}}$ ) promotes the proliferation of $\mathrm{CD} 4+$ and $\mathrm{CD} 8+\mathrm{T}$ cells in vitro. Given the interest in 4-1BB (CD137) as a marker of therapeutically effective tumor-infiltrating lymphocytes (TILs), SPD-4-1BBL will be a useful growth factor for TIL manufacturing and T cell culturing in general.

'Multimeric Biotherapeutics, Inc., La Jolla, CA, USA

Full list of author information is available at the end of the article
Authors' details

${ }^{1}$ Multimeric Biotherapeutics, Inc., La Jolla, CA, USA. ${ }^{2}$ University of Miami, Miller School of Medicine, Miami, FL, USA.

Published: 6 November 2014

doi:10.1186/2051-1426-2-S3-P246

Cite this article as: Kornbluth et al:: Multimeric forms of 4-1BBL as stimulators of T cells for adoptive immunotherapy. Journal for ImmunoTherapy of Cancer 2014 2(Suppl 3):P246.

Submit your next manuscript to BioMed Central and take full advantage of:

- Convenient online submission

- Thorough peer review

- No space constraints or color figure charges

- Immediate publication on acceptance

- Inclusion in PubMed, CAS, Scopus and Google Scholar

- Research which is freely available for redistribution 